\title{
Granulocyte Colony-stimulating Factor Producing Anaplastic Carcinoma of the Pancreas: Case Report and Review of the Literature
}

\author{
SARAH VINZENS ${ }^{1 *}$, JOEL ZINDEL ${ }^{2 *}$, MARTIN ZWEIFEL $^{1}$, TILMAN RAU ${ }^{3}$, \\ BEAT GLOOR $^{2}$ and ANNETTE WOCHNER ${ }^{2}$ \\ ${ }^{1}$ Department of Medical Oncology, University Hospital Bern, Bern, Switzerland; \\ ${ }^{2}$ Department of Visceral Surgery, University Hospital Bern, Bern, Switzerland; \\ ${ }^{3}$ Institute of Pathology, University of Bern, Bern, Switzerland
}

\begin{abstract}
We report on the case of a 67-year-old man with granulocyte colony-stimulating factor $(G-C S F)$ producing anaplastic carcinoma of the pancreas. Preoperative routine tests revealed an elevated white blood cell (WBC) count of $25.2 \mathrm{G} / \mathrm{l}$, consisting almost exclusively of neutrophilic granulocytes $(23.31 \mathrm{G} / \mathrm{l})$ with a predominance of segmented neutrophils (78\% of all neutrophilic granulocytes), and elevated levels of $C$-reactive protein at $87 \mathrm{mg} / \mathrm{l}$. Upon surgery, local tumour infiltration was more extensive than expected from preoperative imaging. However, no peritoneal dissemination was found and curative resection was attempted. Only seven days after the operation, signs of relapse were seen upon computed tomograpy. Histology revealed an undifferentiated anaplastic carcinoma, on the basis of a poorly differentiated ductal adenocarcinoma. Immunohistochemistry demonstrated G-CSF and G-CSFReceptor expression in some CD68-positive syncytial macrophages. Granulocyte colony-stimulating factor $(G-C S F)$ in serum was elevated at $5.6 \mathrm{pg} / \mathrm{ml}$, which further raised to $43 \mathrm{pg} / \mathrm{ml}$ one week after FOLFIRINOX chemotherapy (oxaliplatin, irinotecan, 5-fluorouracil), while WBC decreased from $103.3 \mathrm{G} / \mathrm{l}$ to $59.3 \mathrm{G} / \mathrm{l}$. Granulocyte macrophage-colony stimulating factor $(G M-C S F)$ in serum was normal $(<0.5 \mathrm{pg} / \mathrm{ml})$. The patient died on postoperative day 34 .
\end{abstract}

\footnotetext{
*These Authors contributed equally to this study.

Correspondence to: Martin Zweifel, MD, Ph.D., Department of Medical Oncology, University Hospital Bern, 3010 Bern, Switzerland. Tel: +41 316324114, Fax: +41 316324116, e-mail: martin.zweifel@insel.ch" martin.zweifel@insel.ch
}

Key Words: Anaplastic carcinoma of the pancreas, granulocyte colony-stimulating factor, leukocytosis, neutrophilic granulocyte, paraneoplastic syndrome, chemotherapy.
G-CSF producing pancreatic cancer is a rare tumour entity with dismal prognosis. No standard treatment has been established so far. Further studies are needed to elucidate the potential autocrine stimulation through co-expression of GCSF and G-CSF-Receptor and the different cellular sources and role of G-CSF in the aggressive nature of the disease. Neutrophilia, due to the production of cytokines such as GCSF and GM-CSF in solid tumours, is a rare albeit welldescribed phenomenon. To our knowledge, only 13 cases have been reported so far, including our case.

\section{Case Report}

We report on a case of a 67-year-old man who was diagnosed with anaplastic carcinoma of the pancreatic tail. The patient reported a four-month history of left upper abdominal pain, loss of appetite, and weight loss of $9 \mathrm{~kg}$. Computed tomography (CT) showed a 7-cm lesion in the pancreatic tail and enlarged peripancreatic lymph nodes but no signs of distant metastasis (Figure 1). The patient was planned to undergo resection with curative intent. Preoperative routine tests revealed an elevated white blood cell count (WBC) of 25.2 G/1 (Figure 2) and an elevated C-reactive protein (CRP) of $87 \mathrm{mg} / \mathrm{L}$ (data not shown). Leukocytosis consisted almost exclusively of neutrophilic granulocytes $(23.31 \mathrm{G} / 1)$ with a predominance of segmented neutrophils (78\% of all neutrophilic granulocytes, data not shown).

Upon laparotomy, no peritoneal dissemination was found. However, local tumour infiltration was more extensive than expected based on preoperative imaging. Multivisceral resection was performed including left pancreatectomy, splenectomy, partial gastrectomy and resection of the left colonic flexure. Despite a favourable postoperative course, the patient's WBC continued to increase after a nadir of $24 \mathrm{G} / 1$ on the fourth postoperative day (Figure 2). Suspecting bacterial infection, empirical antibiotic treatment with 


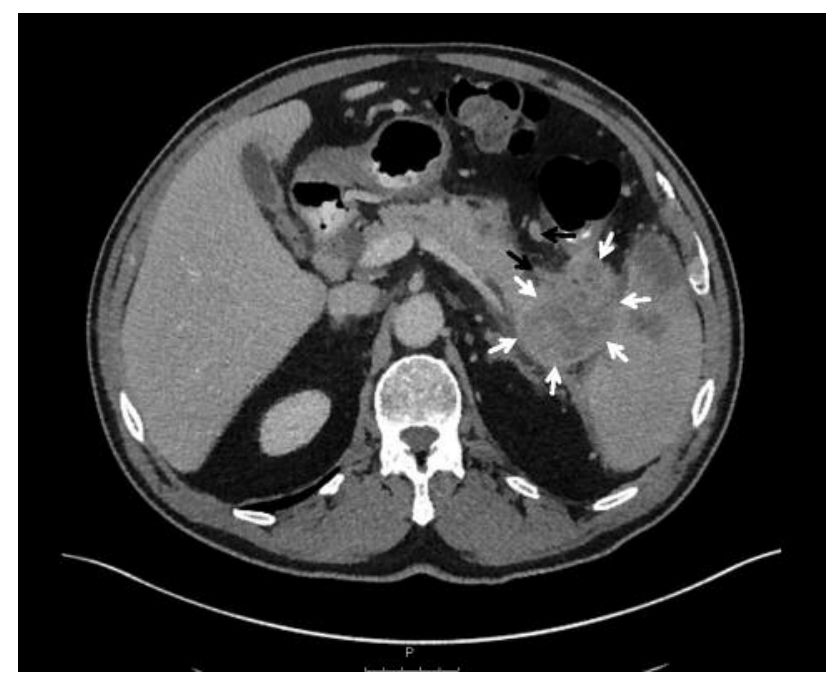

Figure 1. Computed tomography of a 67-year-old man diagnosed with anaplastic carcinoma of the pancreatic tail. A 7-cm lesion in the pancreatic tail (white arrows) and enlarged peripancreatic lymph nodes (black arrows) can be seen.

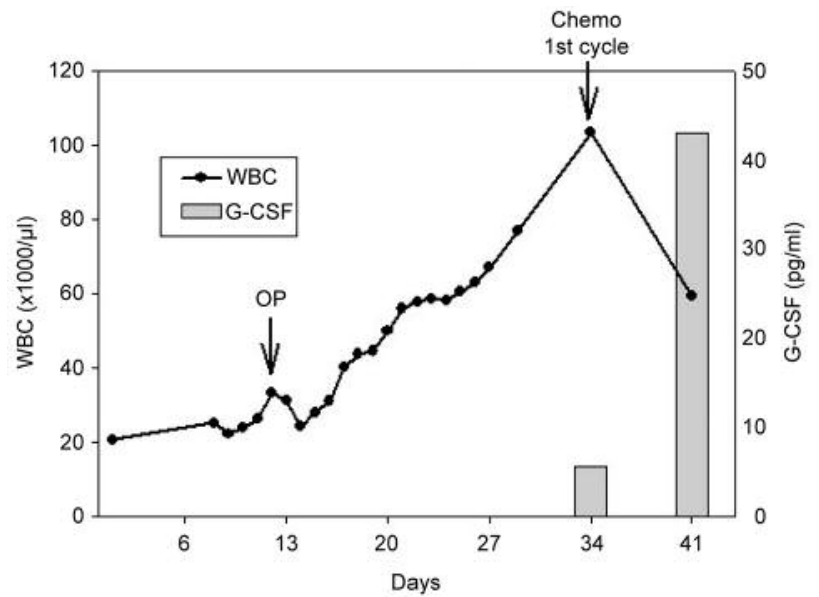

Figure 2. White blood cell counting (WBC, $\times 1000$ cells/ $\mu l=G / l$; left vertical axis) and granulocyte colony-stimulating factor levels (G-CSF, $\mathrm{pg} / \mathrm{ml}$; right vertical axis) in the serum before and after the operation as well as at the first cycle of FOLFIRINOX chemotherapy. Even though $W B C$ count decreased after both, the operation and the chemotherapy, an increase of G-CSF was observed after the 1st cycle of chemotherapy. piperacillin-tazobactam was started and switched to meropenem-vancomycin when WBC further increased. However, the patient was in good condition and had no fever. Repeat blood cultures did not show growth of any germs. CT scan was repeated seven days after the operation, showing new enlarged lymph nodes with central necrosis retropancreatically and thus confirming fast growth of relapsed tumour.

Histology revealed an undifferentiated anaplastic carcinoma, on the basis of a poorly differentiated ductal adenocarcinoma (maximum diameter $13.5 \mathrm{~cm}$ ) with diffuse infiltration of the peripancreatic tissue, lymphovascular and perineural infiltration as well as breaching of the serosa. Union for International Cancer Control (UICC) TNMclassification was pT3 pN1 (24/35) pM1 (5/5 peritoneal lymph nodes). Tumour grade was G4 and surgical margins were not clear microscopically (R1). Immunohistochemical staining analysis of serial sections was performed (Figure 3 ). Giant cells were seen upon haematoxylin-eosin (HE) staining (Figure 3A) and since they were CD68-positive might represent syncytial macrophages (Figure 3B), some of them staining positive for granulocyte colony-stimulating factor (G-CSF, Figure 3C), while approximately half of them staining positive for granulocyte colony-stimulating factorreceptor (G-CSF-R, Figure 3D). G-CSF was also elevated in serum at $5.6 \mathrm{pg} / \mathrm{ml}$ (Figure 2), confirming the paraneoplastic nature of neutrophilia with ectopic production of G-CSF. GM-CSF in serum was normal $(<0.5 \mathrm{pg} / \mathrm{ml})$. Therefore, antibiotics were stopped. The patient recovered well from the operation despite further increase in WBC count and was discharged on the 19th postoperative day in good clinical condition. Total WBC count at the time of discharge was 76 G/1 (Figure 2).

The patient was started on chemotherapy 24 days after the operation. The FOLFIRINOX regimen was chosen as it was shown to be associated with a survival advantage compared to gemcitabine single agent chemotherapy (1). Treatment consisted of oxaliplatin $85 \mathrm{mg} / \mathrm{m}^{2}$ IV on $\mathrm{d} 1$, irinotecan $180 \mathrm{mg} / \mathrm{m}^{2} \mathrm{IV}$ on $\mathrm{d} 1$, and 5 -fluorouracil IV bolus $400 \mathrm{mg} / \mathrm{m}^{2}$ on $\mathrm{d} 1$ and as a continuous infusion of 1,200 $\mathrm{mg} / \mathrm{m}^{2} / \mathrm{d}$ on days 1 and 2 , repeated every two weeks (1). Prior his 1 st cycle of chemotherapy, the patient's WBC increased to $103.3 \mathrm{G} / 1$. Chemotherapy was well tolerated without significant side effects during the first week. On day 8 of chemotherapy, WBC decreased to $59.3 \mathrm{G} / 1$ but, interestingly, serum G-CSF increased to $43 \mathrm{pg} / \mathrm{ml}$ (Figure 2). Unfortunately, the patient decided to stop chemotherapy for personal reasons, was lost to follow-up and died shortly thereafter, on postoperative day 34 .

\section{Discussion}

G-CSF induced neutrophilia is commonly seen in carcinomas of the lung and in undifferentiated carcinoma. Patients with paraneoplastic leukaemoid reactions typically are clinically stable despite having large tumour burdens. However, clinical outcomes are poor unless effective antineoplastic treatment is received (2). To our knowledge, only 13 cases 
Table I. Reported cases of granulocyte colony-stimulating factor producing pancreatic cancer.

\begin{tabular}{|c|c|c|c|c|c|c|c|c|c|c|c|}
\hline Case & $\begin{array}{l}\text { Age } \\
(\mathrm{yrs})\end{array}$ & Gender & r Symptoms & $\begin{array}{l}\text { WBC } \\
(\mathrm{G} / \mathrm{L})\end{array}$ & $\begin{array}{c}\text { Neutrophilic } \\
\text { granulocytes } \\
(\%)\end{array}$ & $\begin{array}{c}\text { G-CSF } \\
(\mathrm{pg} / \mathrm{mL}) \\
\text { (normal value) }\end{array}$ & $\begin{array}{l}\text { Cellular } \\
\text { localisation } \\
\text { of G-CSF }\end{array}$ & $\begin{array}{l}\text { CRP } \\
(\mathrm{mg} / \mathrm{dl})\end{array}$ & Histology & Treatment $\mathrm{S}$ & $\begin{array}{c}\text { Survival } \\
\text { (days) }\end{array}$ \\
\hline (17) & 71 & $\mathrm{~m}$ & ND & 71.3 & ND & 650 & ND & ND & Pancreatic carcinoma & ND & ND \\
\hline (16) & 72 & $\mathrm{f}$ & ND & 61 & 91 & $86(<60)$ & ND & ND & ND & ND & ND \\
\hline (18) & 64 & $\mathrm{~m}$ & Fever & 24.3 & 93 & $157(<30)$ & $\begin{array}{l}\text { (Negative for } \\
\text { all cells) }\end{array}$ & 0.62 & Anaplastic carcinoma & Operation & 56 \\
\hline (12) & 83 & $\mathrm{~m}$ & Back pain & 15.7 & 81 & $123(6.0-21.9)$ & $\begin{array}{l}\text { Squamous } \\
\text { carcinoma } \\
\text { cells (but not } \\
\text { adenomatous) }\end{array}$ & ND & $\begin{array}{l}\text { Poorly differentiated } \\
\text { adenosquamous } \\
\text { carcinoma }\end{array}$ & $\begin{array}{l}\text { Chemotherapy: } \\
\text { 5-fluorouracil, } \\
\text { pirarubicin, } \\
\text { mitomycin-C }\end{array}$ & 120 \\
\hline (14) & 60 & $\mathrm{~m}$ & $\begin{array}{l}\text { Weight loss, } \\
\text { fever }\end{array}$ & 28.9 & 70 & $77(<30)$ & $\begin{array}{c}\text { Adenocarcinoma } \\
\text { cells }\end{array}$ & 15.16 & $\begin{array}{l}\text { Poorly differentiated } \\
\text { adenocarcinoma }\end{array}$ & Palliative care & 46 \\
\hline (7) & 50 & $\mathrm{~m}$ & Leukocytosis & 49.18 & ND & $350(5-15)$ & $\begin{array}{c}\text { Adenocarcinoma } \\
\text { cells }\end{array}$ & ND & $\begin{array}{l}\text { Poorly differentiated } \\
\text { adenocarcinoma }\end{array}$ & Palliative care & 20 \\
\hline (15) & 46 & $\mathrm{~m}$ & General fatigue & 14.3 & $83.7 \%$ & $155(5.78-27.5)$ & ND & 4.6 & Anaplastic carcinoma & Operation & 120 \\
\hline (9) & 56 & $\mathrm{~m}$ & $\begin{array}{l}\text { Back pain, } \\
\text { fever }\end{array}$ & 18.7 & 81 & 62 & Tumour cells & 13.99 & $\begin{array}{l}\text { Pancreatic ductal } \\
\text { adenocarcinoma }\end{array}$ & $\begin{array}{l}\text { Chemotherapy: } \\
\text { S-1 gemcitabine }\end{array}$ & 135 \\
\hline (13) & 74 & $\mathrm{~m}$ & $\begin{array}{l}\text { Fever, general } \\
\text { fatigue }\end{array}$ & 29.5 & ND & $110(<18.1)$ & $\begin{array}{l}\text { Pancreatic cancer } \\
\text { cells (cytoplasmic) }\end{array}$ & 15.9 & $\begin{array}{l}\text { Poorly differentiated } \\
\text { adenocarcinoma }\end{array}$ & Operation & 42 \\
\hline (11) & 63 & $\mathrm{~m}$ & $\begin{array}{l}\text { Weight loss, } \\
\text { upper abdominal } \\
\text { pain }\end{array}$ & 91.5 & 87.5 & $134(<18.1)$ & $\begin{array}{c}\text { Pancreatic cancer } \\
\text { cells }\end{array}$ & ND & $\begin{array}{c}\text { Anaplastic } \\
\text { pleomorphic- } \\
\text { type carcinoma }\end{array}$ & - & 11 \\
\hline (8) & 89 & $\mathrm{f}$ & $\begin{array}{l}\text { Weight loss, } 4 \\
\text { fever }\end{array}$ & 45.86 & 96 & $690(<18.1)$ & $\begin{array}{l}\text { Atypical cells } \\
\text { (adenosquamous } \\
\text { carcinoma) }\end{array}$ & 11.98 & $\begin{array}{l}\text { Poorly differentiated } \\
\text { adenosquamous } \\
\text { carcinoma }\end{array}$ & Palliative care & 62 \\
\hline (10) & 68 & $\mathrm{~m}$ & $\begin{array}{c}\text { Fever, weight } \\
\text { loss }\end{array}$ & 17.5 & ND & $355(<39)$ & Tumour cells & 13.2 & Anaplastic carcinoma & $\begin{array}{c}\text { Chemotherapy: } \\
\text { S-1 }\end{array}$ & 83 \\
\hline $\begin{array}{l}\text { Our } \\
\text { case }\end{array}$ & 67 & $\mathrm{~m}$ & $\begin{array}{l}\text { Weight loss, } \\
\text { upper abdominal } \\
\text { pain }\end{array}$ & 25.2 & 92.5 & 5.6 & $\begin{array}{c}\text { Syncytial } \\
\text { macrophages }\end{array}$ & 87 & $\begin{array}{l}\text { Undifferentiated } \\
\text { anaplastic } \\
\text { carcinoma }\end{array}$ & $\begin{array}{c}\text { Operation and } \\
\text { chemotherapy: } \\
\text { oxaliplatin, } \\
\text { irinotecan, } \\
\text { 5-fluorouracil }\end{array}$ & 34 \\
\hline
\end{tabular}

of G-CSF producing pancreatic cancers have been reported summarized in Table I.

In these published cases, mean age of patients was 66 years (range, 46 to 89 years), with a predominance of male vs. female patients $(85 \%$ vs. $15 \%)$. Most patient presented with fever, back and/or upper abdominal pain and a history of weight loss. WBC count at the time of diagnosis ranged from 14.3 to $91.5 \mathrm{~g} / 1$, while 70 to $91 \%$ of the white blood cells consisted of neutrophilic granulocytes. In most patients, mild elevations of CRP were seen, which were not as prominent as one would expect in a bacterial infection with similar high WBC count. Histologically, most patients presented with anaplastic or poorly differentiated adenocarcinoma, while two patients suffered from poorly differentiated adenosquamous carcinoma. The clinically aggressive course of disease is in line with the poorly differentiated/anaplastic histology of all tumours, if reported, and is reflected by the dismal prognosis. In 4 of 13 patients an operation could be attempted, and only 4 of 13 patients received chemotherapy. Median survival of the published cases of G-CSF producing pancreatic cancer was 56 days, which is considerably shorter than the 2 to 6 months seen in stage IV pancreatic cancer in general (3).

In our patient, an attempt was made using a relatively aggressive triplet of chemotherapy (oxaliplatin, irinotecan, and 5-fluorouracil), resulting in a reduction of WBC from 103 to $59 \mathrm{G} / 1$ within one week. However, since the patient decided to stop all therapy despite good tolerance to the chemotherapy, it's not possible to know if this more aggressive chemotherapy regimen would have resulted in better efficacy than single agent chemotherapy (1). Two observations are of interest in our case: the increase of serum G-CSF levels after chemotherapy, while at the same time WBC count decreased, and immunohistochemical localisation of both, G-CSF and GCSF-Receptor in syncytial macrophages.

An inverse relationship between endogenous G-CSF serum levels and circulating neutrophil counts has been reported, which might explain the increase of G-CSF one 

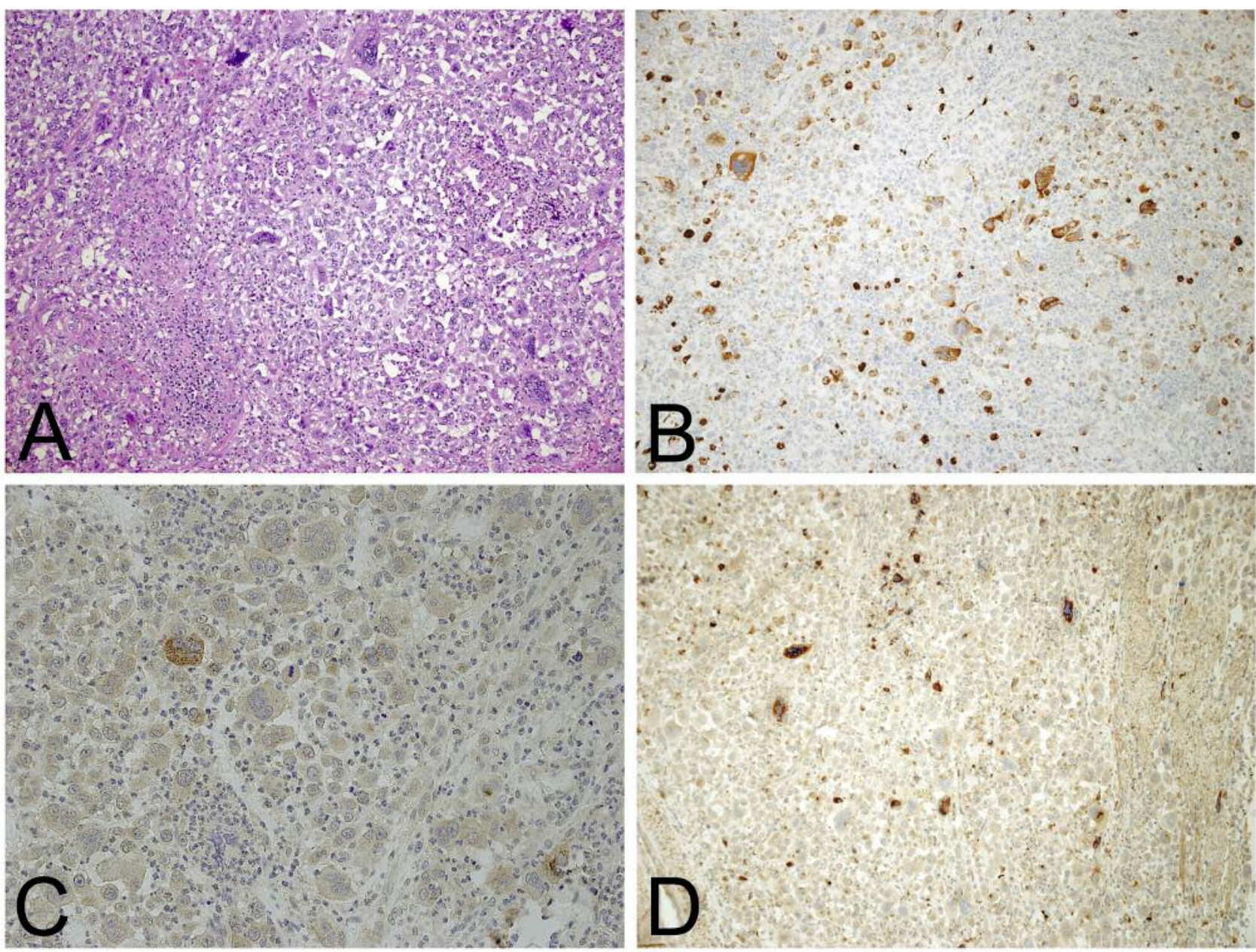

Figure 3. Histochemistry and immunohistochemistry of serial sections (100x). (A) Giant cells in an undifferentiated anaplastic carcinoma of the pancreas are seen upon haematoxylin-eosin (HE) staining. (B) Macrophages and giant cells stained positive for CD68. Giant cells, thus, are syncitial macrophages. (C) Some of the CD68-positive giant cells stain positive for G-CSF. (D) Approximately half of the CD68 positive giant cells stain positive for G-CSF-Receptor.

week after chemotherapy in our patient, despite a decreased in WBCs $(4,5)$. Since the first description of plasma G-CSF elevation in nude mice transplanted with human lung cancer (6), more than 100 cases of G-CSF producing tumours have been described, including virtually all solid tumours and some haematological neoplasias. While cells of the monocyte/macrophage lineage are among the most prominent sources of G-CSF, malignant cell lines derived from numerous cell types have been shown to be capable of constitutively secreting large amounts of G-CSF (4). In 8 of the 12 published cases of G-CSF producing pancreatic cancer, G-CSF could immunohistochemically confined to tumour cells (7-14). In three, no staining results were reported (15-17) and in one, staining remained negative for G-CSF in all cells (18). However, the ability to produce GCSF is characteristic of a variety of cell types following appropriate stimulation, including tumour necrosis factor (TNF) (19), interleukin (IL) 1 (20, 21), IL3 (22), IL4 (23), GM-CSF $(22,24)$ and interferon- $\gamma$ (IFNG) $(25)$. It is possible that in our patient's tumour, some of the syncytial macrophages were stimulated to produce G-CSF. The expression of both, G-CSF and G-CSF-Receptor by the same cells in G-CSF producing tumours has only been described once, in a case of hepatocellular carcinoma (26).

The poor prognosis of G-CSF producing pancreatic cancer may be linked to the elevated G-CSF itself. In fact, a correlation was found between breast cancer cell-derived G-CSF, the production of atypical T-cell-suppressive neutrophils (27), and the overexpression of G-CSF augmenting tumour growth (28), further corroborating the well-described relationship between an increase of circulating neutrophils and poor prognosis in cancer 
patients (29). In summary, we report on a patient with GCSF producing pancreatic cancer, a rare tumour entity with dismal prognosis. No standard treatment has been established so far. Further studies are needed to elucidate the potential autocrine stimulation through co-expression of G-CSF and G-CSF-Receptor and the different cellular sources and role of G-CSF in the aggressive nature of the disease.

\section{References}

1 Conroy T, Desseigne F, Ychou M, Bouche O, Guimbaud R, Becouarn Y, Adenis A, Raoul JL, Gourgou-Bourgade S, de la Fouchardiere C, Bennouna J, Bachet JB, Khemissa-Akouz F, Pere-Verge D, Delbaldo C, Assenat E, Chauffert B, Michel P, Montoto-Grillot $\mathrm{C}$ and Ducreux M: FOLFIRINOX versus gemcitabine for metastatic pancreatic cancer. N Engl J Med 364 1817-1825, 2011.

2 Granger JM and Kontoyiannis DP: Etiology and outcome of extreme leukocytosis in 758 nonhematologic cancer patients: a retrospective, single-institution study. Cancer 115: 3919-3923, 2009.

3 Kayahara M, Nagakawa T, Ueno K, Ohta T, Takeda $\mathrm{T}$ and Miyazaki I: An evaluation of radical resection for pancreatic cancer based on the mode of recurrence as determined by autopsy and diagnostic imaging. Cancer 72: 2118-2123, 1993.

4 Demetri GD and Griffin JD: Granulocyte colony-stimulating factor and its receptor. Blood 78: 2791-2808, 1991

5 Watari K, Asano S, Shirafuji N, Kodo H, Ozawa K, Takaku F and Kamachi S: Serum granulocyte colony-stimulating factor levels in healthy volunteers and patients with various disorders as estimated by enzyme immunoassay. Blood 73: 117-122, 1989.

6 Asano S, Urabe A, Okabe T, Sato $\mathrm{N}$ and Kondo $\mathrm{Y}$ : Demonstration of granulopoietic factor(s) in the plasma of nude mice transplanted with a human lung cancer and in the tumor tissue. Blood 49: 845-852, 1977.

7 Fukushima N, Sasatomi E, Tokunaga O and Miyahara M: A case of pancreatic cancer with production of granulocyte colonystimulating factor. Am J Gastroenterol 96: 258-259, 2001.

8 Joshita S, Nakazawa K, Sugiyama Y, Kamijo A, Matsubayashi $\mathrm{K}$, Miyabayashi $\mathrm{H}$, Furuta $\mathrm{K}$, Kitano $\mathrm{K}$ and Kawa $\mathrm{S}$ : Granulocyte-colony stimulating factor-producing pancreatic adenosquamous carcinoma showing aggressive clinical course Intern Med 48: 687-691, 2009.

9 Kawakami H, Kuwatani M, Fujiya Y, Uebayashi M, Konishi K, Makiyama H, Hashino S, Kubota K, Itoh T and Asaka M: A case of granulocyte-colony stimulating factor producing ductal adenocarcinoma of the pancreas. Nihon Shokakibyo Gakkai Zasshi 104: 233-238, 2007.

10 Kitade H, Yanagida H, Yamada M, Satoi S, Yoshioka K, Shikata $\mathrm{N}$ and Kon M: Granulocyte-colony stimulating factor producing anaplastic carcinoma of the pancreas treated by distal pancreatectomy and chemotherapy: report of a case. Surg Case Rep 1: 46, 2015

11 Nakajima A, Takahashi H, Inamori M, Abe Y, Kobayashi N, Kubota K and Yamanaka S: Anaplastic carcinoma of the pancreas producing granulocyte-colony stimulating factor: a case report. J Med Case Rep 2: 391, 2008.
12 Ohtsubo K, Mouri H, Sakai J, Akasofu M, Yamaguchi Y, Watanabe H, Gabata T, Motoo Y, Okai T and Sawabu N: Pancreatic cancer associated with granulocyte-colony stimulating factor production confirmed by immunohistochemistry. J Clin Gastroenterol 27: 357-360, 1998.

13 Takami K, Miura K, Takeuchi H, Egawa S, Moriya T, Nakamura Y, Tanabe A, Sugita J, Karasawa H, Unno M and Sasaki I: Granulocyte-colony stimulating factor-producing pancreatic cancer: report of a case. Surg Today 38: 453-457, 2008.

14 Yokoi H, Nakata M, Sawai K, Yoshida T, Koshikawa M, Joyama S, Tanaka A, Goto M, Ueda S, Senzaki H, Sugawara A and Kuwahara T: Intraglomerular metastasis from pancreatic cancer. Am J Kidney Dis 37: 1299-1303, 2001.

15 Gotohda N, Nakagohri T, Saito N, Ono M, Sugito M, Ito M, Inoue $\mathrm{K}$, Oda $\mathrm{T}$, Takahashi $\mathrm{S}$ and Kinoshita $\mathrm{T}$ : A case of anaplastic ductal carcinoma of the pancreas with production of granulocyte-colony stimulating factor. Hepatogastroenterology 53: 957-959, 2006.

16 Nakamura K, Takahashi T, Tsuyuoka R, Ueda Y, Suzuki A, Okuno Y, Ihara Y, Seko S, Okada T, Kumagai N, Oyaizu T and Nishimura T: Identification of colony-stimulating factor activity in patients with malignant tumors associated with excessive leukocytosis. Jpn J Clin Oncol 21: 395-399, 1991.

17 Ohwada S, Miyamoto Y, Fujii T, Kuribara T, Teshigawara O, Oyama T, Ishii H, Joshita $\mathrm{T}$ and Izuo M: Colony stimulating factor producing carcinoma of the pancreas - a case report. Gan No Rinsho 35: 523-527, 1989.

18 Uematsu T, Tsuchie K, Ukai K, Kimoto E, Funakawa T and Mizuno R: Granulocyte-colony stimulating factor produced by pancreatic carcinoma. Int J Pancreatol 19: 135-139, 1996.

19 Koeffler HP, Gasson J, Ranyard J, Souza L, Shepard M and Munker R: Recombinant human TNF alpha stimulates production of granulocyte colony-stimulating factor. Blood 70 : 55-59, 1987.

20 Fibbe WE, van Damme J, Billiau A, Goselink HM, Voogt PJ, van Eeden G, Ralph P, Altrock BW and Falkenburg JH: Interleukin 1 induces human marrow stromal cells in long-term culture to produce granulocyte colony-stimulating factor and macrophage colony-stimulating factor. Blood 71: 430-435, 1988.

21 Zsebo KM, Yuschenkoff VN, Schiffer S, Chang D, McCall E, Dinarello CA, Brown MA, Altrock B and Bagby GC Jr.: Vascular endothelial cells and granulopoiesis: interleukin-1 stimulates release of G-CSF and GM-CSF. Blood 71: 99-103, 1988.

22 Oster W, Lindemann A, Mertelsmann R and Herrmann F: Granulocyte-macrophage colony-stimulating factor (CSF) and multilineage CSF recruit human monocytes to express granulocyte CSF. Blood 73: 64-67, 1989.

23 Wieser M, Bonifer R, Oster W, Lindemann A, Mertelsmann R and Herrmann F: Interleukin-4 induces secretion of CSF for granulocytes and CSF for macrophages by peripheral blood monocytes. Blood 73: 1105-1108, 1989.

24 Vellenga E, Rambaldi A, Ernst TJ, Ostapovicz D and Griffin JD: Independent regulation of M-CSF and G-CSF gene expression in human monocytes. Blood 71: 1529-1532, 1988.

25 Herrmann F, Cannistra SA and Griffin JD: T cell-monocyte interactions in the production of humoral factors regulating human granulopoiesis in vitro. J Immunol 136: 2856-2861, 1986. 
26 Kohno M, Shirabe K, Mano Y, Muto J, Motomura T, Takeishi K, Toshima T, Yoshimatsu M, Ijichi H, Harada N, Aishima S, Uchiyama H, Yoshizumi T, Taketomi A and Maehara Y: Granulocyte colony-stimulating-factor-producing hepatocellular carcinoma with extensive sarcomatous changes: report of a case. Surg Today 43: 439-445, 2013.

27 Casbon AJ, Reynaud D, Park C, Khuc E, Gan DD, Schepers K, Passegue E and Werb Z: Invasive breast cancer reprograms early myeloid differentiation in the bone marrow to generate immunosuppressive neutrophils. Proc Natl Acad Sci USA 112: E566-575, 2015.

28 Waight JD, Hu Q, Miller A, Liu S and Abrams SI: Tumor-derived G-CSF facilitates neoplastic growth through a granulocytic myeloid-derived suppressor cell-dependent mechanism. PLoS One 6: e27690, 2011.
29 Templeton AJ, McNamara MG, Seruga B, Vera-Badillo FE, Aneja P, Ocana A, Leibowitz-Amit R, Sonpavde G, Knox JJ, Tran B, Tannock IF and Amir E: Prognostic role of neutrophilto-lymphocyte ratio in solid tumors: a systematic review and meta-analysis. J Natl Cancer Inst 106: 124, 2014.

Received October 18, 2016

Revised November 4, 2016

Accepted November 14, 2016 